\title{
Emigration: a Price of Inequality or a Breach of Social Contract?
}

\author{
Antanas Laurinavicius $^{1}$, Algimantas Laurinavicius ${ }^{2}$ \\ Faculty of Economics, Vilnius University, Sauletekio al. 9, LT-10222 Vilnius, Lithuania \\ E-mails: ${ }^{1}$ antanas.laurinavicius@ef.vu.lt (corresponding author); ${ }^{2}$ algimantas.laurinavicius@ef.vu.lt
}

Received 07 February 2017; accepted 05 April 2017

\begin{abstract}
The society in our country has been struck by the emigration crisis of an unprecedented scope in Europe since World War II. Lithuania also stands out among the EU member states as a state with a particularly low level of trust, whereas the primary institutions of a democratic civil society, i.e. the Government, political parties, and the Parliament, are all at the bottom in the list of institutions ranked according to the level of trust.

Although the growth of the average income and assets of the population was truly impressive over the past 20 years, this did not stop emigration neither slowed it down. This means that merely higher income is not enough for people; in fact, happiness is mostly correlated to equality of income (relative wealth) rather than to increase of income (absolute wealth).

In the framework mentioned above the article provides a comprehensive analysis of the causes of emigration and suggests effective strategic decisions to stop the emigration using strategic thinking and strategic synthesis methods.
\end{abstract}

Keywords: contract theory, trust, inequality, emigration.

JEL Classification: D63, D86, O15.

Conference topic: Sustainable Economics Development.

\section{Introduction}

The Society in our country has been struck by the biggest emigration crisis, which Europe has not witnessed since World War II. As the State has found itself at the edge of self-destruction, even the part of the Society which is normally not keen on contemplating cannot help but naturally wonder (even though it is way overdue) how this biggest political / social / economic crisis in Lithuania should have been dealt with during the period of our Independence. It would be a great lesson for the future and a great textbook example of strategic illiteracy, strategic mistakes, and unrealized strategic opportunities if it was not our nation we were talking about. At the same time, it is a perfect occasion to reconsider all the successful and unsuccessful efforts, the results of previous programs (approved ones and the ones which were attempted to implement), to evaluate the differences in these results as compared to the desired results and expectations. It is also a period when we have to honestly answer (first of all to ourselves) the questions what driving forces and factors determined the social-economic development of the State and the Society over the past quarter of the century. It is also the time to ask (ourselves) what mistakes have been made and what has not been done at all. This is the price of strategic mistakes and strategic illiteracy in particular.

"In any partnership, you are as strong as your weakest partner is", said Donald J. Trump, President-Elect of the USA (Trump, Schwartz 2015). The same idea resonated in the criticism of the future President of the USA towards the members of the NATO failing to meet their obligations, including Lithuania. Moreover, this idea is relevant in another aspect as well: it is important to realise that our country is as strong as its weakest member is; it is just as strong as the four-fifths of a million of emigrants. And all this happened without any contribution of famine, like in Ireland in the $19^{\text {th }}$ century; war, like in Syria today; or other natural disasters. All this came as no much of a surprise to anyone and without ringing the alarm on a daily basis! It is true that we used to find comfort in the idea that people were running away in search for a better life abroad. But is it really the case? That is, was it really the only reason? Is it possible that this wishful thinking, this self-reassurance encouraged even bigger emigration, because the tools chosen to fight emigration were wrong? Isn't the neo-liberal economic doctrine ${ }^{1}$ and the goal to catch up with the Western European countries as fast as possible by only calculating the GDP per capita that frightened people causing an opposite effect? Isn't it about time to admit that the plan "to catch up with and surpass the most developed

${ }^{1}$ A paradox: how compatible are the Social Democrats who remained in power for 15 years out of 25 years of Independence and the neo-liberal economic doctrine pursued in Lithuania at the same time?

(C) 2017 A. Laurinavicius, Al. Laurinavicius. Published by VGTU Press. This is an open-access article distributed under the terms of the Creative Commons Attribution (CC BY 4.0) License, which permits unrestricted use, distribution, and reproduction in any medium, provided the original author and source are credited. 
capitalist countries of Europe" failed? This is because the economic growth is slowing and it is already below the average of the EU while the wave of emigration keeps going strong: this is the price of "fire-fighting" and desperate (not strategic!) decisions. Thus, what actually has lead (and still leads) to the ongoing emigration?

\section{The theory of contracts: from J. J. Rousseau to O. Hart and B. Holmstrom}

In 2016 the Nobel Prize in Economic Sciences was awarded to O. Hart, Professor at Harvard University, and B. Holmstrom, Finnish-born scientist working at the University of Massachusetts, for their research in analysing the theory of contracts. The research done by these authors is particularly relevant to all countries (including Lithuania) with functional market economy, where exchange of goods and services is based on market relations, whereas additional incentives increase personal interest, initiative, and innovations, labour efficiency, and hence economic development of the entire country.

Contracts are an essential functional factor of a modern society. The research done by O. Hart and B. Holmstrom sheds some light on how contracts help in regulating contradictory and conflicting interests of various parties. Contracts encourage and oblige cooperation and trust, whereas without them there would be no obedience or trust. All relations are governed by contracts in today's modern society: employees have employment contracts, separate contracts are made by managers and business owners, borrowers have credit contracts whereas property owners have insurance contracts. Some contracts can be laid down on a single page, others are one hundred pages long or even longer.

One of the reasons for concluding a contract is anticipation and regulation of future actions. For instance, employment contracts may provide a bonus for good performance as well as reasons for termination of employment. Contracts may have other purposes as well, such as fair division of risks among the contracting parties.

Whereas a potential for a conflict often is associated with mutual relations of the parties, contracts need to be prepared properly so that the contracting parties would make mutually beneficial decisions. O. Hart and B. Holmstrom's theory of contracts gives tools for understanding the structure of contracts governing various areas of life and analysing such phenomena as result-dependant regulation of executive wages by means of employment contracts, application of deductions in insurance contracts, or privatization of public sector activities. One of the objectives of this theory is to explain why there are different forms and designs of contracts. Another objective is to help understanding how to prepare better contracts consequently forming better social institutions. Should providers of public services, such as schools, hospitals, or prisons, be classified as the ones pertaining to the public sector or to the private sector? Should teachers, doctors, and prison guards be paid a fixed wage or a variable one depending on their performance and results (Nobel Prize Committee 2016)?

Thanks to O. Hart and B. Holmstrom, both scholars in economy, and practitioners representing business or the public sector have more instruments at their disposal for analysing not only financial provisions of contracts, but also optimum contractual distribution of ownership, control, or decision making rights.

The theory of contracts indicates that the best contract is the one combining an optimum balance of risk and incentives. It encourages people in charge to pursue innovations simultaneously maintaining the necessary prudence. The best illustration of the above statements is an example of an insurance contract.

Each insurance contract provides a deduction, i.e. a part of losses which must be compensated by the policyholder himself/ herself in case of an insured event. This is because insurers do not believe in mere coincidences. If insurers believed that all insured events were accidental, all insurance contracts would compensate losses in full. However, such full compensation of losses would stimulate a moral hazard, i.e. if we knew that insurance would cover losses in full, we would be less cautious as compared to knowing that we ourselves would have to contribute to compensation of losses.

In this case, a contraposition of remuneration (i.e. full compensation of losses) and incentives of a person (i.e. his/ her inappropriate activities) results from two causes. The first one is the conflict of interests: i.e. not every individual can overcome the moral hazard. If everyone behaved with equal amount of care in both cases, i.e. if the damage was paid by yourself or if it was covered by your insurer, in that case full insurance would be no problem. The second problem is evaluation: not all our actions could be perfectly monitored and evaluated. If insurers could notice every careless action, in that case insurance could compensate full losses resulting from actually accidental events, rather than from the ones resulting from our negligence. It should be noted that such partial compensation of losses is relevant not only in case of insurance contracts but also in case of mutual relations of the executive and the shareholders. Partial compensation of losses may be relevant not only in case of loss of profit but also in case of evaluation of strategic mistakes made by the executive and the consequences of those mistakes.

The same contraposition is characteristic to other types of contracts as well, e.g., employment contracts, where the employee's interests may sometimes differ from the ones of the employer, and the latter is not always able to supervise the employee (e.g., what is an optimum contract between the owner of the company and the manager whose work and activities cannot be seen in full scope by the owner himself/ herself?). In that case, typical employment contracts with fixed wage, as an instrument for ensuring security and insurance of the employee, are no 
longer sufficient, the employee needs additional incentives related to his/ her performance (additional incentives may be expressed not only in the form of a monetary remuneration but also as career opportunities).

During the early stages of B. Holmstrom career his research work was focused on analysis of an employee who deals with one task (Holmstrom 1979). Later on, he moved on to analysing more realistic situations, when an employee deals with many different tasks and some of them are complicated for the employer to supervise, evaluate, and remunerate (Holmstrom, Milgrom 1991). In that case, it is advisable to offer small equal incentives for the entire work so that the employee would not focus on tasks with easily measurable results. For instance, if a teacher's wage depended on easily measurable graduation examination results of his/ her student's, such a teacher could focus only on this area neglecting other ones, such as development of children's creativity or independent thinking. Meanwhile a fixed wage independent of any results achieved by students would encourage such a teacher to distribute his/ her energy more evenly for all the aforementioned tasks. The results of this B. Holmstrom's model covering different tasks encouraged economists to reconsider optimum remuneration schemes and employment models.

The theory developed by O. Hart discussed cases when contracts could not clearly anticipate all future possibilities and scenarios (Hart, Moore 1988; Hart, Tirole 1988). Such contracts shall stipulate who should be entitled to make decisions regarding further actions when parties would not be able to reach an agreement. A party holding such a right to make decisions would have more powers in negotiations and, obviously, would be able to negotiate a better contract for one's own benefit. In turn this would motivate such a party to make decisions, such as investments, but, on the other hand, it will result in reduced incentives for the party with fewer rights to make decisions. In complex contractual situations assignment of the right of making decisions to one of the parties becomes a good alternative for remuneration depending on results.

O. Hart also analysed how wages of the top executives are / should be associated with achievements. This covers not only the profit made by the company but also the perceived strategic idea of a team, new opportunities, new markets, a completely different level of satisfaction of consumers.

The regularities observed by O. Hart and B. Holmstrom and the theories developed by them are relevant both in the private sector, where relationships in all areas are based on contracts, and the public sector, where relationships with the citizens are based on written agreements (e.g., laws, codes, regulations, directives, etc.) and sometimes on unwritten agreements (e.g., codes of conduct, moral standards, etc.).

Although the insights of O. Hart and B. Holmstrom's theory of contracts are undeniably important for the modern society, which bases its functioning on contracts, nevertheless the origins of the theory of contracts could be traced back to the political - philosophical work by the French philosopher Jean-Jacques Rousseau "The Social Contract" ("Du contrat social") issued two and a half centuries ago. Here the author emphasizes "since no man has a natural authority over his fellow, and force creates no right, we only have agreements as the basis for all legitimate authority among men" (Rousseau 2006).

In his work Jean-Jacques Rousseau also speaks about the primal and the most important contract by which citizens, who are full of trust, establish their State by refusing a part of their private interests for the benefit of the common ones: "there's only one law that from its very nature needs unanimous consent, namely the social contract; for civil association is the most voluntary of all acts. $<\ldots>$ So if the social contract has opponents at the time when it is made, their opposition doesn't invalidate the contract; it merely prevents them from being included in it, making them foreigners among citizens. Once a State has been instituted, residence constitutes consent; to live within its territory is to submit to its sovereignty. $<\ldots>$ Apart from its primal contract, the vote of the majority always binds all the rest. This follows from the contract itself."

What a relevant observation for Lithuania! Even two and a half centuries later none of these statements have lost their relevance. Don't these thoughts accurately reflect the biggest social problem encountered by our country in the $21^{\text {st }}$ century? "Once a state has been instituted, residence constitutes consent; to live within its territory is to submit to its sovereignty" and "if the social contract has opponents at the time when it is made, <...> [they are] foreigners among citizens". Mass emigration is a statement made by the citizens, who left our state, that they are terminating the previously concluded social contract. They leave and become "foreigners among citizens", who are no longer bound by the primal unwritten agreement, also referred to as the social contract.

But what are the reasons of this? Why do these citizens decide to become foreigners and refuse this contract? How this could be explained by "The Social Contract" published by J. J. Rousseau in the $18^{\text {th }}$ century or by the Theory of Contracts published by O. Hart and B. Holmstrom in the $20^{\text {th }}$ century?

The advices given by Jean-Jacques Rousseau are easily understandable and incredibly relevant even today: "do you want the state to be solid? Then make the wealth-spread as small as you can; don't allow rich men or beggars. These two conditions are naturally inseparable: any state that has very wealthy citizens will also have beggars, and vice versa. And they are equally fatal to the common good: one produces supporters of tyranny, the other produces tyrants. It is always between them that public liberty is put on sale: one buys, the other sells".

O. Hart and B. Holmstrom speak about trust as one of the key factors involved in conclusion of contracts.

Major social inequality, particularly deteriorated trust in the State and its institutions are those key factors which violate the social contract forcing a part of the residents to move abroad as they become "foreigners among citizens". This is the price of distrust and inequality. 
It should be noted that distrust of the public institutions and social inequality is growing in other Western countries as well and the protest voice of the citizens of these countries have been loud and clear during the recent voting in the United Kingdom and the USA (which supported Brexit and D. Trump). Many thinkers even rushed to declare the end of the neo-liberal doctrine and to claim that "the end of history" anticipated by F. Fukuyama (Fukuyama 1992) with domination of the liberal democracy "forever" and the European Union as the best reflection of his notion of the end of history might never turn into reality.

\section{A crisis of trust}

Modern social science disciplines state that any controlled system is stable only when synergetic horizontal and vertical relations between its parts (sub-systems) have been developed in line with relations between its management institutions. Developed synergetic relations indicate presence of high-level trust between parts of the system and its individual members in a specific system (society).

Implementation of long-term investment projects, great ideas-constructs are only possible in case when the whole of the state's institutions, cultural standards, business practices, and legal systems stimulates the sense of trust. According to T. L. Friedman, "if you want more people to take the required risks in order to achieve innovations, just trust them more. If the society has a low level of trust, it will never develop long-term novelties" (Friedman 2005). F. Fukuyama claims that "the welfare of the nation as well as its potential for competition depends on one cultural characteristic: the level of trust characteristic to the society" (Fukuyama 1995). Thus, in case of lack of trust, any implemented policy will bring little efficiency.

Meanwhile major distrust, miscommunication (i.e. discontinuous synergetic relations) among the government and science institutions, business structures, public organizations, municipalities, etc. is noticeable in our state and society (Smilga 2012). Based on the representative survey of the EU member states focusing on their trust in the state's Government and the judicial system conducted by Gallup in 2011, Lithuania stood out as a state with a particularly low level of trust, which was significantly below the average of the EU and the Western European countries (Bertane 2011). Based on the findings of the survey on European values conducted in 2014, only 31\% of the Lithuanian population expressed trust in the state's Parliament and only $25 \%$ of them expressed trust in political parties, meanwhile the average in other surveyed European states was 53\% and $39 \%$. As compared to Estonia, these indices were $52 \%$ and $34 \%$ (European... 2014). Based on the findings of the most recent public survey conducted in Lithuania ("Vilmorus" survey, 1-10 July 2016) only 19\% of the state's population trusted the Government, only $8 \%$ of them trusted the Parliament, and only $8 \%$ of them trusted political parties. The latter three institutions were all at the bottom in the list of all institutions ranked according to the level of trust.

We may conclude that Lithuania stands out among the EU member states as a state with a particularly low level of trust and the primary institutions of a democratic civil society, i.e. the Government, political parties, and the Parliament, have lost the public trust and credibility.

\section{Emigration and income}

Having discussed the impact of trust on emigration, it is important to analyse a popular assumption that emigration was determined by the average income or assets of the population. There are many arguments in Lithuania to support this: low average salary of the Lithuanian population, low level of national income and low ratio of national income to the EU average. However, whenever relying on this argument, we undeservedly forget that:

a) the average monthly wage in the national economy increased by 5 times over the past 20 years (if we started from 1993 when Litas was introduced, the rise of wages would account for 15 times) (Statistics Lithuania 2016);

b) the gross domestic product per capita increased by 6 times during the same period (20 years);

c) the ratio of Lithuanian gross domestic product per capita and the average of the EU gross domestic product per capita increased more than twice within 20 years, i.e. from approximately 20 percent in 1995 to almost 45 percent in 2015 (Eurostat 2016).

The increase of indices over the past 20 years is truly impressive, however, it did not stop emigration neither slowed it down. This means that merely higher income is not enough. Possibly this is because people do not feel happier depending to increase of income (Laurinavičius et al. 2016). This is evident from the findings of the longstanding household surveys conducted by institutions in the USA, UK, and Germany (Fig. 1).

It appears that happiness (measured as a subjective perception of well-being) was not increasing along with growing income during the long period and it was even decreasing in certain periods (probably in relation to other circumstances). In fact, happiness is more correlated to equality of income (relative wealth) than increase of income (absolute wealth). Naturally, citizens of different countries have different levels of tolerance when it comes to inequality: the Scandinavians are traditionally considered to be supporters of a state which redistributes welfare, meanwhile the Americans tend to agree with a significant index of inequality. For this reason, it is evident that changes in inequality would probably have different impact on the quality of life in different countries and this is 
precisely why international comparisons are problematic. Nevertheless, in 2004 Alesina et al. (Alesina et al. 2004) found a significant negative correlation between inequality of income and life satisfaction in the USA and even more
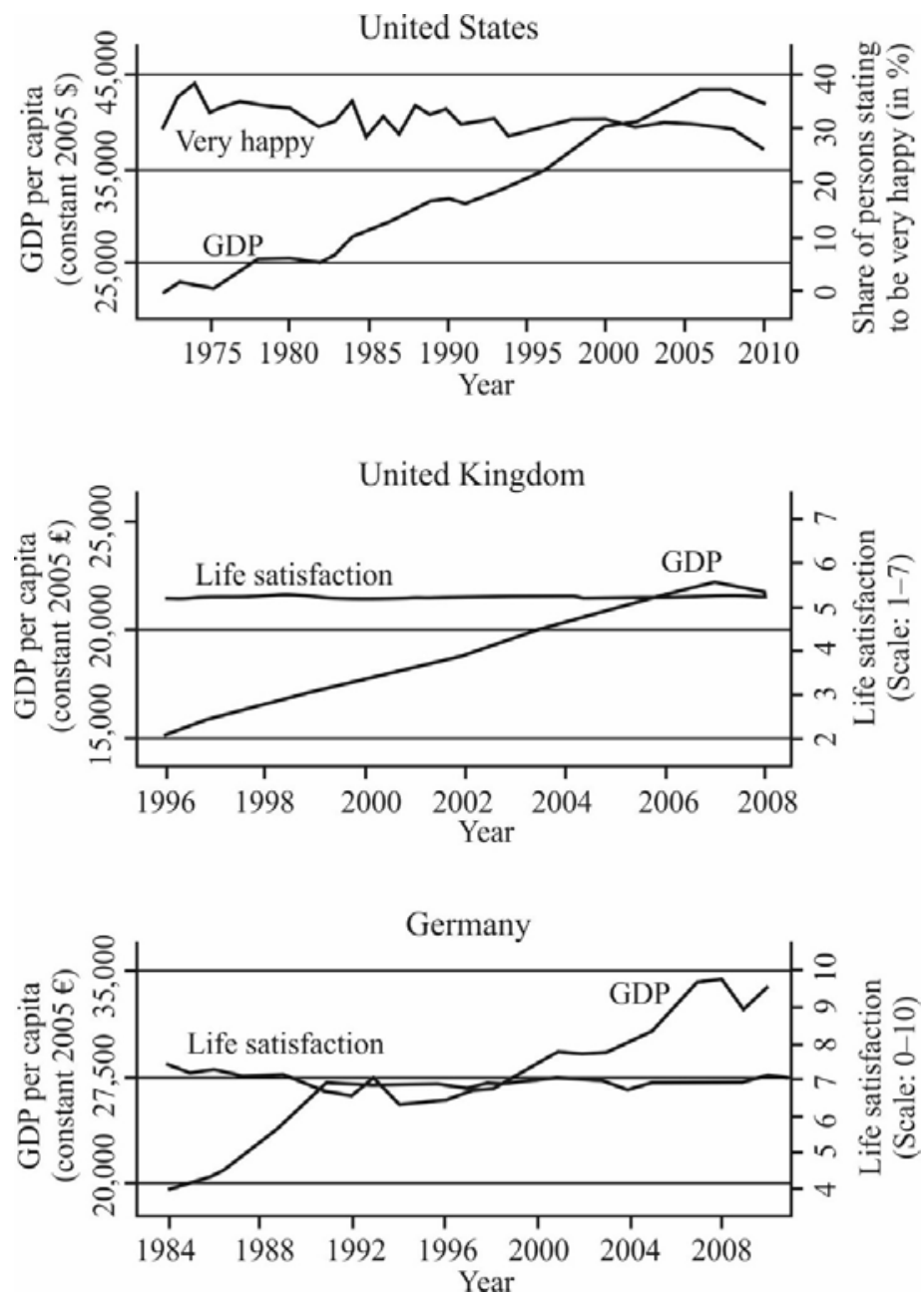

Fig. 1. Income and life satisfaction (Source: Weimann et al. 2015)

significant negative correlation in Europe. Detailed study findings indicate that poor citizens and voters supporting the left-wing politicians demonstrate higher intolerance of inequality, while richer citizens and voters supporting the right-wing politicians are more indifferent to distribution of income.

Another study conducted by Oishi et al. in 2011 (Oishi et al. 2011) based on the US-related data over the period of 1972-2008 explained the reasons why inequality of income made people unhappy: because of the aforementioned trust and fairness. Weaker trust and depressed sense of fairness reduced people's life satisfaction during the period of higher inequality of income. Moreover, Stiglitz provided a detailed description of how inequality of income violates the principle of the rule of law (Stiglitz 2013).

\section{Shocking statistics}

Lithuania has lost almost half a million people (or 14 percent) since joining the EU (in 2004). In the previous section attempts were made to deny the prevailing opinion that emigration was caused only by low income of the population. However, the opinion that emigration was stimulated by Lithuania's succession to the EU also deserves some criticism for at least a couple of reasons:

1. The scale of emigration from the country was just as impressive even before Lithuania joined the EU. The total population of Lithuania decreased by 815 thousand or 22 percent over the 25 years of Independence (1991-2015) (Eurostat 2016).

2. So many people have not "fled" other new EU member states when they joined the EU: the Lithuanian rate is the worst one accross the EU. Therefore, joining the EU and free movement of the population within the EU should not be deemed as the sole cause of emigration of the Lithuanian people either. 
Figure 2 presents population change (in percentage) in the new EU member states (which joined the EU at the same time as Lithuania or later) from the beginning of 2005 to the end of 2015. It is evident that Lithuania is a clear "leader" based on these statistics.

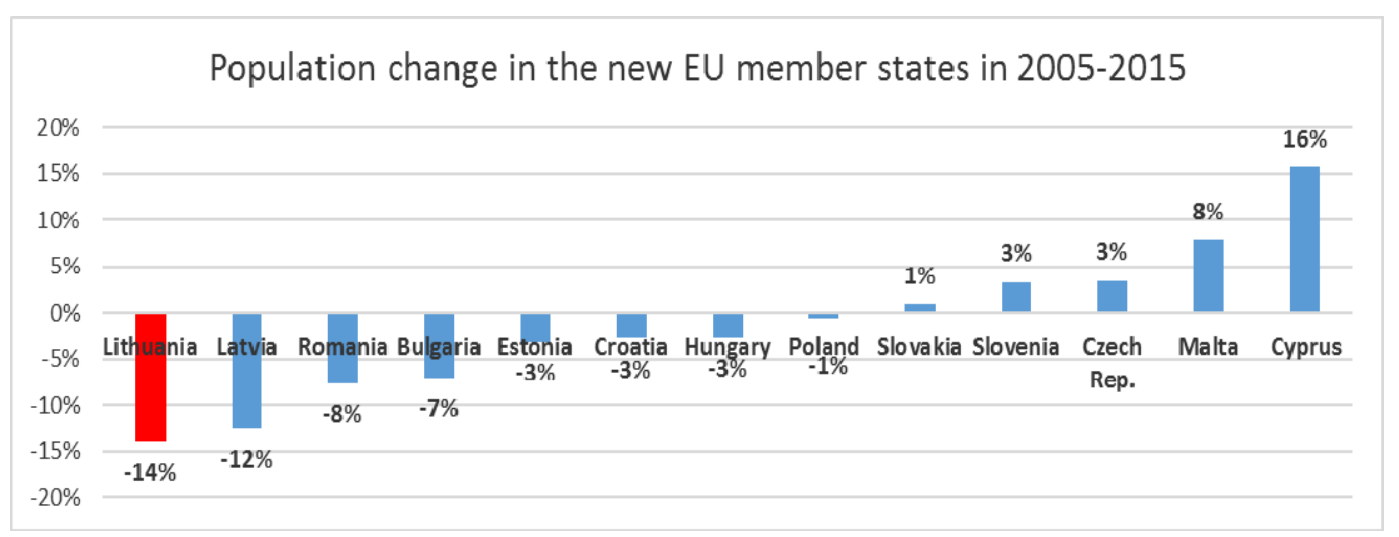

Fig. 2. Population change rate in the new EU member states in 2005-2015

(Source: concluded by the authors, based on the data of Eurostat 2016)

Moreover, Figure 3 presents the scale of emigration from the new EU member states (with the exception of Malta and Cyprus as the population in these countries increased significantly over the decade since joining the EU, as can be seen in Fig. 2) year by year. It appears that most of the people "fled" Lithuania right after the crisis in 2010. Every $38^{\text {th }}$ resident of Lithuania (or 2.6 percent of the entire population) left the country in just one year! This was an absolute "record" of the EU both in that year and in general. In addition to that, Lithuania was the "leader" among the new EU member states in this area not only in 2010 but during the entire period since joining the EU, with the exception of 2008, when it was "surpassed" by Romania and Latvia (but Lithuania still ranked third), and 2009 (when Lithuania was second to Latvia).

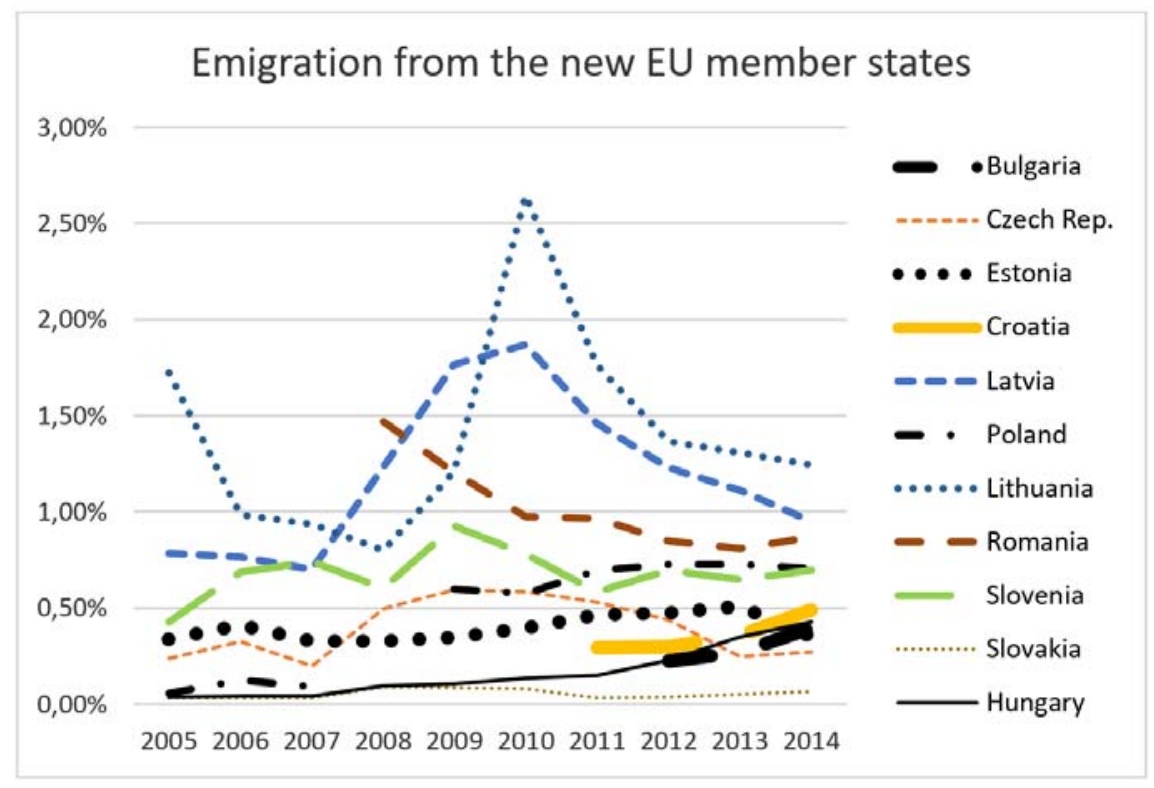

Fig. 3. Emigration from the new EU member states in 2005-2014

(Source: concluded by the authors, based on the data of Eurostat 2016)

The question is what causes emigration, if joining the EU is not a crucial factor and the growth of economic welfare in the State is not strong enough to encourage people to stay? As we have already mentioned in the previous section, it is much likely that emigration is stimulated by the lack of happiness in a broad sense, which is primarily associated with relative welfare, i.e. equality (or inequality) of income, rather than with absolute wealth (or absolute income). 
This theoretical assumption can be based on empirical data: not only the highest rate of emigration has been recorded in Lithuania out of all the EU member states year by year but Lithuania is also a country with highest income inequality (Fig. 4)!

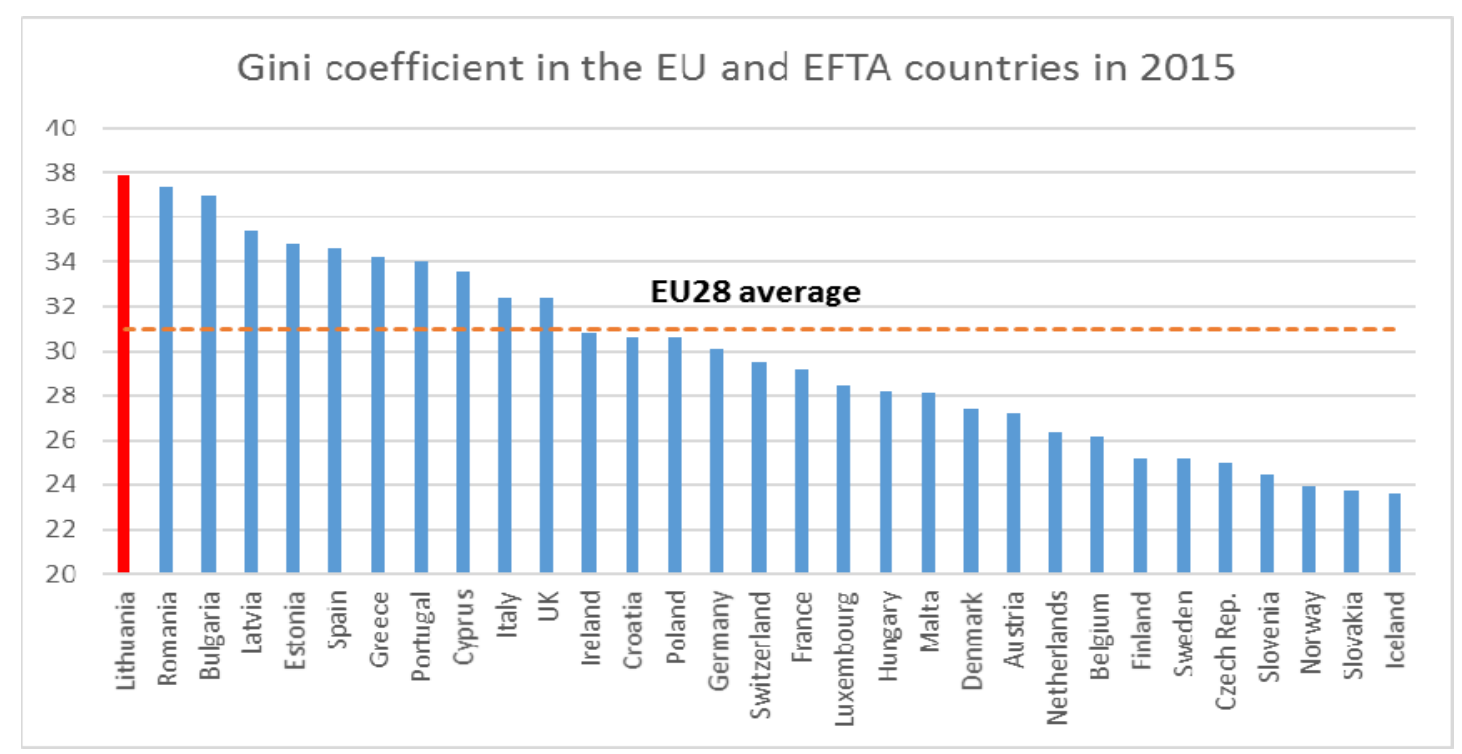

Fig. 4. Gini coefficient in the EU and EFTA (Switzerland, Norway, Iceland) countries in 2015 (Source: concluded by the authors, based on the data Eurostat 2016)

To make matters even worse, not only the income inequality was the highest in Lithuania as compared to the entire EU, but also it increased even more over the past decade (2005-2015) despite the fact that the State's economy increased by even 72 percent (Fig. 5). Hence, as a result of wrong decisions and actions of the Government, rapid growth of the Lithuanian economy not only failed to reduce social inequality in Lithuania but even increased it.

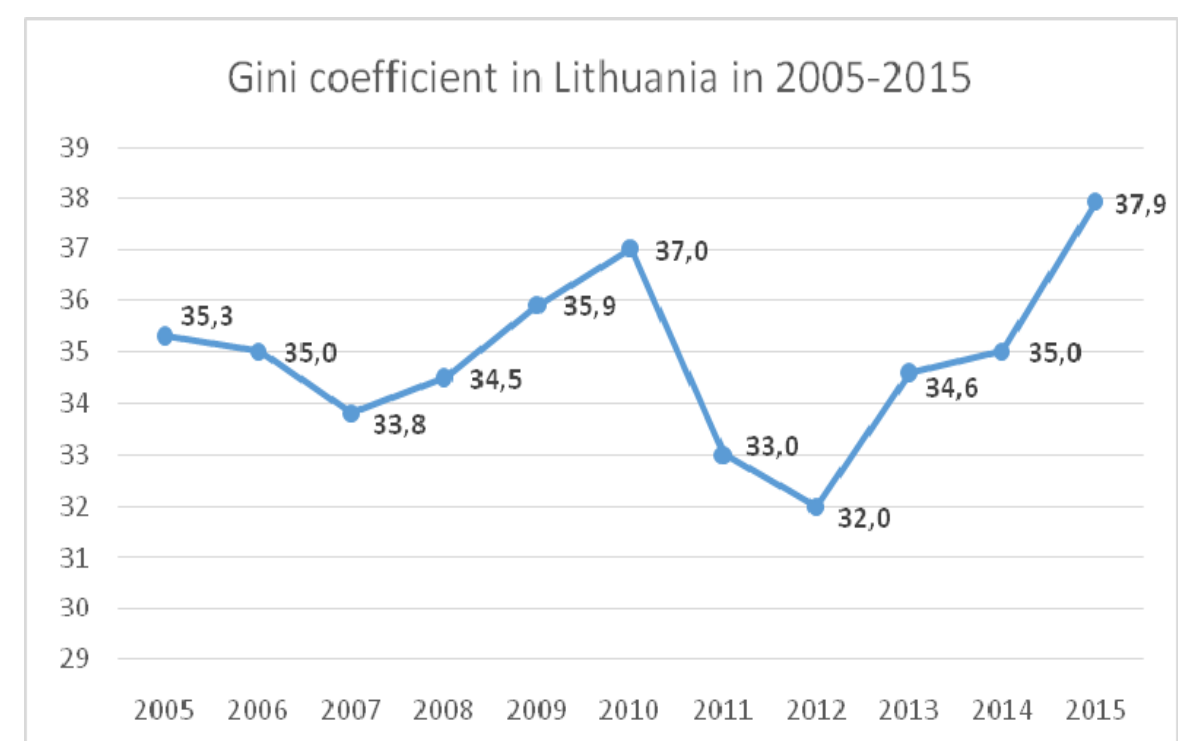

Fig. 5. Gini coefficient in Lithuania in 2005-2015

(Source: concluded by the authors, based on the data Eurostat 2016; World bank 2016)

The Gini coefficient is used for measuring inequality of income distribution and it is a variable ranging from 0 to $100 \%$, where 0 indicates complete social equality (everyone earns equal wages) and $100 \%$ indicates complete inequality (a single individual receives all income of the State). This coefficient shows that social equality in Lithuania was declining before the crisis in 2008, it kept increasing during the crisis and right after it, and has declined again since 2010 along with recovery of the economy. However, in 2012 it started increasing again and it still keeps increasing! 
Based on the findings of the conducted studies, in addition to increased emigration, greater inequality reduces people's trust in fair society offering equal opportunities, and it also overwhelms the sense of community. Greater inequality also has an adverse impact on economy as a result of lower productivity, efficiency, and growth as well as greater instability. Lower economic growth has been proven by analysing data of many countries over long-term periods (Stiglitz 2013). Most importantly, it is evident that almost a quarter of the nation has been lost over a quarter of the century, and this is the price of inequality.

\section{Ways to reduce inequality}

Based on the material given in the paper, it is evident that first and foremost we need to fight lack of trust and social inequality in order to reduce the scope of emigration. Naturally, we should start with applying stricter and more efficient laws on competition and better corporate governance. We should reduce hidden subsidies to companies (governments spend money on large companies too often instead of helping people who actually need help). Many subsidies to companies are hidden in tax laws: exceptions, exemptions, reduced tariffs. More simple laws on profit and personal income tax with fewer exceptions would also be useful to reduce inequality (Stiglitz 2013). Simultaneous increase of taxation of income generated by property and, possibly, taxation of property itself $^{2}$ and reduction of taxation of employment-related income would also be helpful.

These actions should be followed by the creation of appropriate social architecture: transformation of generally accepted behaviour standards and the implied hierarchy of values: to decide which values should prevail, which patterns of behaviour should be encouraged. This requires an effective education system which would encourage savings and investments, as well as development of a new class of investors. Implementation of an asset-based policy by opening savings accounts for all new born children could become a reference point (Laurinavičius, Al., Laurinavičius, An. 2016). Finally, social security system could be more effective and, possibly, trade unions stronger as well as collective employment agreements mandatory.

Building trust in public institutions is another task which should be given a top priority. This requires a new and properly educated generation of strategists ready to make needed changes in the existing institutions, to adapt them to the best global practice and to constantly changing reality. This context highlights the need for a local team of strategists, a creative core of the society, local elite in education-culture-politics-finances and a network-based strategic management system.

\section{Conclusions}

The research done by O. Hart and B. Holmstrom, the winners of the Nobel Prize in Economic Sciences in 2016, the propositions presented in the theory of contracts, and the suggested methods for dealing with contradictions between remuneration and personal incentives are relevant to Lithuania as well, especially when analysing the consequences of failure to comply with the Social Contract, which have become the most urgent problem in the beginning of the $21^{\text {st }}$ century, i.e. mass emigration of the population.

The society in our country has been struck by the emigration crisis of an unprecedented scope in Europe since World War II. The population in Lithuania decreased by 815 thousand or 22 percent within the 25 years of Independence (1991-2015). This rate is the worst one accross the EU.

Lithuania also stands out among the EU member states as a state with a particularly low level of trust, whereas the primary institutions of a democratic civil society, i.e. the Government, political parties, and the Parliament, are all at the bottom in the list of institutions ranked according to the level of trust.

Although the growth of the average income and assets of the population over the past 20 years is truly impressive, this did not stop emigration neither slowed it down. This means that merely higher income is not enough for people. Possibly the reason of this is that people do not feel happier (when happiness is measured as a subjective perception of well-being) along with increase of income and assets. In fact, happiness is mostly correlated to equality of income (relative wealth) rather than to increase of income (absolute wealth).

Income inequality in Lithuania is biggest in the entire EU and it increased even more over the past decade (2005-2015) while the State's economy increased by even 72 percent. Thus, we may claim that, as a result of wrong decisions and actions of the Government, rapid growth of the Lithuanian economy not only failed to reduce inequality but even increased it. We may conclude that the neo-liberal economic doctrine and the plan "to catch up with and surpass the most developed capitalist countries of Europe" failed.

Major social inequality, particularly deteriorated trust in our own State and its institutions are the key factors which violated the social contract forcing a part of the population, who have become "foreigners among citizens", to move abroad. Hence, emigration is the price of distrust and inequality. Moreover, mass emigration is a statement by our citizens that they are terminating the previously concluded social contract.

\footnotetext{
${ }^{2}$ Nevertheless, taxation of property itself does not change the marginal decisions of employees/ investors/ consumers, thus the benefits of this type of taxation require more comprehensive debates.
} 
The first step towards reduction of emigration is fighting lack of trust and social inequality. Development of a proper strategic architecture could be one of the tools. This requires an effective education system encouraging savings and investments as well as development of a new class of investors. Implementation of an asset-based policy by opening savings accounts for all newborns as well as building trust in public institutions could become a reference point. This requires a properly educated new generation of strategists.

\section{References}

Alesina, A.; Di Tella, R.; MacCulloch, R. 2004. Inequality and happiness: are Europeans and Americans different? Journal of Public Economics 88: 2009-2042. https://doi.org/10.1016/j.jpubeco.2003.07.006

Bertane, C. 2011. National Governments Get Low Marks in the EU [online], [cited 23 February 2017]. Available from Internet: http://www.gallup.com/poll/151715/national-governments-low-marks.aspx

European Social Survey [online], 2014 [cited 23 February 2017]. Available from Internet: http://www.europeansocialsurvey.org/download.html?file=ESS7LT\&c=LT\&y=2014

Eurostat 2016 [online], [cited 23 February 2017]. Available from Internet: http://ec.europa.eu/eurostat

Friedman, T. L. 2005. The world is flat: a brief history of the twenty-first century. New York: Farrar, Straus and Giroux.

Fukuyama, F. 1992. The end of history and the last man. New York: Free Press.

Fukuyama, F. 1995. Trust: social virtues and the creation of prosperity. New York: Free Press.

Hart, O.; Moore, J. 1988. Incomplete Contracts and Renegotiation, Econometrica 56(4). https://doi.org/10.2307/1912698

Hart, O.; Tirole, J. 1988. Contract Renegotiation and Coasian Dynamics, Review of Economic Studies 55(184). https://doi.org/10.2307/2297403

Holmstrom, B. 1979. Moral hazard and observability, The Bell Journal of Economics 10(1): 74-91. https://doi.org/10.2307/3003320

Holmstrom, B.; Milgrom, P. 1991. Multitask principal-agent analyses: incentive contracts, asset ownership, and job design, Journal of Law, Economics, \& Organization 7: 24-52. https://doi.org/10.1093/jleo/7.special_issue.24

Laurinavičius, Al.; Laurinavičius, An. 2016. The concept of basic income: global experience and implementation possibilities in Lithuania, Business, Management and Education 14(1): 50-63. https://doi.org/10.3846/bme.2016.306

Laurinavičius, Al.; Laurinavičius, An.; Smilga, E. 2016. The social economic development strategies: creation of a strong state and modern economy [Socialinès ekonominès raidos strategijos: stiprios valstybès ir modernios ekonomikos kūrimas], Viešasis administravimas 1-2(49-50): 8-18.

Nobel Prize Committee. 2016. Oliver Hart and Bengt Holmström: Contract theory, Nobel Prize in Economics documents $2016-1$.

Oishi, S.; Kesebir, S.; Diner, E. 2011. Income inequality and happiness, Psychological Science 23: 86-92. https://doi.org/10.1177/0956797611420882

Rousseau, J.-J. 2006. Du contrat social ou principes du droit politique. Boston: Adamant Media Corporation.

Smilga, E. 2012. Untapped possibilities of strategic management [Neišnaudotos strateginio valdymo galimybè], Mokslas ir technika 7-8.

Statistics Lithuania 2016 [online], [cited 23 February 2017]. Available from Internet: http://www.stat.gov.lt/

Stiglitz, J. E. 2013. The Price of Inequality. London: Penguin Books.

Trump, D. J.; Schwartz, T. 2015. The art of the deal. New York: Random House.

Weimann, J.; Knabe, A.; Schoeb, R. 2015. Measuring happiness. The economics of well-being. Cambridge: MIT Press.

World bank. 2016. Indicators [online], [cited 23 February 2017]. Available from Internet: http://data.worldbank.org/indicator 